\title{
Pengelolaan Anestesi untuk Seksio Sesarea Kehamilan Triplet dengan Skor LAS Intraoperatif 6
}

\author{
Dewi Yulianti Bisri*), Tatang Bisri**) \\ ${ }^{*}$ Departemen Anestesiologi dan Terapi Intensif, Fakultas Kedokteran Universitas Padjadjaran/RS Dr. Hasan \\ Sadikin Bandung, ${ }^{* *}$ Departemen Anestesiologi dan Terapi Intensif, Fakultas Kedokteran Universitas Jenderal \\ Achmad Yani Cimahi-Bandung-Rumah Sakit Melinda Bandung
}

\begin{abstract}
Abstrak
Triplet (kembar tiga) dan kehamilan kembar yang lebih banyak lagi (higher multiple gestations) dihubungkan dengan peningkatan morbiditas ibu dan anak dibandingkan dengan kehamilan ganda atau kehamilan tunggal. Seksio sesarea adalah rute yang disukai untuk melahirkan pasien dengan kehamilan triplet. Seorang wanita, 31 tahun, G1P0A0 gravida aterm triplet hasil inseminasi, BB 72,5 kg, TB $168 \mathrm{~cm}$, Mallampati 1, tekanan darah 130/90 $\mathrm{mmHg}$, laju nadi $97 \mathrm{x} / \mathrm{menit}, \mathrm{SpO}_{2} 100 \%$ dengan kanul binasal. Induksi dengan propofol $140 \mathrm{mg}$, atracurium 35 $\mathrm{mg}$, intubasi dengan pipa endotrakheal no 6,5. Ventilasi mekanik dengan volume tidal $560 \mathrm{~mL}$, laju nafas $12 \mathrm{x}$ per menit, postive end expiratory pressure (PEEP) 5. Rumatan anestesi dengan $\mathrm{N}_{2} \mathrm{O} 40 \%$, sevofluran 1-2 vol\%. Analgetik fentanyl 100 ug diberikan setelah bayi lahir. Cairan RL 1500 mL, gelofusin 500 mL. Obat-obat lain: misoprostol $800 \mathrm{mcg}$ perrectal, oxytocin $40 \mathrm{IU}$, methylergometrine 0,6 mg, asam traneksamat 1 gram, dextrose 40\% 25 mL. Bayi ke-1 BB 2650 gr, pada jam 19.1, Apgar score 1 menit dan 5 menit 9, 10, Bayi ke-2 BB 2100 gr, Apgar score 1 menit dan 5 menit 9, 10, Bayi ke-3 BB 1900 gr, Apgar score 1 menit dan 5 menit 9, 10 lahir selang 1 menit. Tidak terjadi hipotensi, dan karena skor linear analog scale (LAS) 4-6 setelah terapi medikal maka dilakukan pengikatan uterus dengan tehnik B-Lynch suture, tidak terjadi postpartum hemorrhage, Hb postoperatif $10 \mathrm{~g} / \mathrm{dL}$, hematokrit 29\%, tidak dilakukan transfusi darah. Analgetik pascabedah dengan petidin $100 \mathrm{mg}$ dan dexketoprofen $100 \mathrm{mg}$ dilarutkan dalam $\mathrm{NaCl}$ 0,9\% $500 \mathrm{~mL}$ yang diberikan untuk 24 jam.
\end{abstract}

Kata kunci: anestesi, jahitan B-Lynch, kehamilan triplet, perdarahan postpartum, seksio sesarea, skor LAS

\section{Anesthesia Management for Caesarean Section Triplet Pregnancy with Intraoperative LAS Score 6}

\begin{abstract}
Triplet and higher multiple gestations associated with increase maternal and fetal morbidity compare with twin or singleton pregnancy. Caesarean section is route for delivery patient with triplet gestations. A woman, 31 years, G1P0A0 gravida aterm triplet insemination result, BW 72,5 kg, height $168 \mathrm{~cm}$, Mallampati 1, blood pressure $130 / 90 \mathrm{mmHg}$, heart rate $97 \mathrm{x} / \mathrm{minute}, \mathrm{SpO}_{2} 100 \%$ with canul binasal. Induction anesthesia with propofol 140 $\mathrm{mg}$, atracurium $35 \mathrm{mg}$, intubated with endotracheal tube no 6,5. Mechanical ventilation with tidal volume 560 $\mathrm{mL}$, respiratory rate $12 \mathrm{x}$ per minutes, postive end expiratory pressure (PEEP) 5. Maintenance anesthesia with $\mathrm{N}_{2} \mathrm{O} 40 \%$, sevoflurane 1-2 vol\%. Analgetic fentanyl 100 ug given after baby delivery. Fluids with RL 1500 $\mathrm{mL}$, gelofusin $500 \mathrm{~mL}$. Other drugs are misoprostol $800 \mathrm{mcg}$ perrectal, oxytocine $40 \mathrm{IU}$, methylergometrine $0.6 \mathrm{mg}$, tranexamic acid 1 gram, dextrose 40\% $25 \mathrm{~mL}$. First baby BW 2650 gr, Apgar score 1 minute and 5 minute 9, 10 at 19.21, second baby BW 2100 gr, Apgar score 1 minute and 5 minute 9, 10, third baby BW 1900 gr, Apgar score 1 minute and 5 minute 9, 10 delivered 1 minute interval. No evidence of hypotension and linear analog scale (LAS) score is 4-6 and so needed uterus binding with B-Lynch suture technique, no evidence of postpartum hemorrhage, postoperative $\mathrm{Hb} 19 \mathrm{~g} / \mathrm{dL}$, hematocrit $29 \%$, no blood transfusion. Postoperative analgesia with petidine $100 \mathrm{mg}$ and dexketoprofen $100 \mathrm{mg}$ in $\mathrm{NaCl} 0,9 \% 500 \mathrm{~mL}$ for 24 hours.
\end{abstract}

Key words: anesthesia, caesarean section, LAS Score, postpartum hemorrhage, triplet pregnancy, B-Lynch suture 


\section{Pendahuluan}

Triplet (kembar tiga) dan kehamilan ganda yang lebih banyak lagi (higher multiple gestations) dihubungkan dengan peningkatan morbiditas ibu dan anak dibandingkan dengan kehamilan ganda atau kehamilan tunggal. Peningkatan risiko neonatal adalah terutama berhubungan dengan iatrogenik atau kelahiran preterm: rata-rata umur kehamilan untuk melahirkan pada triplet, kembar ganda, atau hamil tunggal adalah 32, 35, dan 39 minggu. ${ }^{1,2}$ Penelitian pada salah satu institusi di Amerika, kelahiran per vagina pasien dengan triplet lebih tinggi tanpa meningkatkan morbitas. ${ }^{3}$

Anestesi spinal untuk seksio sesarea pasien kehamilan triplet dihubungkan dengan peningkatan kejadian hipotensi maternal dan hipoperfusi placenta. Satu penelitian tentang efek anestesi regional untuk seksio sesarea pada kehamilan triplet terhadap outcome maternal dan neonatal yang membandingkan antara anestesi spinal dengan anestesi epidural untuk melihat hemodinamik intraoperatif dan outcome neonatal. Hasil penelitian menunjukkan bahwa terdapat penurunan tekanan darah, kebutuhan cairan intravena dan efedrin pada kelompok anestesi spinal, akan tetapi, APGAR skor tidak berbeda. Simpulannya adalah anestesi spinal dan anestesi epidural aman dilakukan untuk seksio sesarea kehamilan triplet. ${ }^{4}$

Masalah anestesi/operasi untuk seksio sesarea pada kehamilan ganda adalah efek penekanan aortocaval yang lebih besar, efek peregangan uterus yang menimbulkan gangguan kontraksi uterus pasca lahir. ${ }^{4}$ Kehamilan ganda dihubungkan dengan meningkatnya kejadian diabetes mellitus gestational. Laju diabetes mellitus gestational lebih tinggi pada triplet daripada hamil tunggal. ${ }^{5}$ Seksio sesarea adalah rute yang disukai untuk melahirkan pasien dengan kehamilan triplet. Melahirkan pervaginal pasien triplet dihubungkan dengan meningkatnya risiko kelahiran mati, dan kematian neonatal dan infant dibandingkan dengan dilahirkan dengan seksio sesarea. ${ }^{6}$ Postpartum hemorrhage (PPH) secara tradisional didefinisikan sebagai kehilangan darah $>500 \mathrm{~mL}$ setelah persalinan pervagina atau
$>1000 \mathrm{~mL}$ setelah seksio sesarea. ${ }^{7}$ Postpartum hemorrhage disebut berat bila kehilangan darah $>1000 \mathrm{~mL}$ setelah persalinan per vagina atau adanya hemodinamik yang tidak stabil. Akan tetapi, definisi PPH masih diperdebatkan karena beberapa penelitian yang baru telah menunjukkan bahwa median kehilangan darah setelah persalinan pervagina melebihi $500 \mathrm{~mL}{ }^{7}$

Postpartum hemorrhage diklasifikasikan sebagai PPH primer dan PPH sekunder. Postpartum hemorrhage primer terjadi selama 24 jam pertama sedangkan PPH sekunder dimaksudkan dengan perdarahan antara 24 jam sampai 6 minggu setelah melahirkan. ${ }^{8,9}$ Postpartum hemorrhage dapat diklasifikasikan sebagai primer bila terjadi dalam 24 jam setelah melahirkan atau sekunder yang terjadi 24 jam sampai 12 minggu postpartum. Postpartum hemorrhage primer lebih sering terjadi daripada PPH sekunder. ${ }^{7}$ Penyebab umum PPH adalah atonia uteri, sisa plasenta, laserasi obstetrik, inversi uteri, dan penggunaan tokolitik sebelum persalinan. Atonia uteri sering disebabkan karena overdistensi uterus (kehamilan kembar dan polihidramnion), dan yang jarang adalah karena gangguan proses pembekuan. ${ }^{10}$

Kekuatan kontraksi uterus dapat dilakukan dengan pemeriksaan skor Linear Analog Scale (LAS). ${ }^{11}$ Makin banyak bayi yang ada dalam uterus, makin besar peregangan dan kemungkinan terjadinya atonia uteri sangat besar. Kejadian PPH pada gemeli meningkat. ${ }^{9}$ Pilihan pertama uterotonika adalah oxytocin, tetapi bila kontraksi LASnya $<6$ dapat diberikan methylergometrin intravena atau intramuskular, bila kontraksi masih tidak baik dapat diberikan prostaglandin per rectal.

\section{Kasus}

\section{Anamnesa}

Seorang wanita, 31 tahun, G1P0A0 gravida aterm triplet hasil inseminasi. Masuk RS Melinda 1 Bandung dan direncanakan untuk dilakukan seksio sesarea. Riwayat asthma bronchiale tidak ada, alergi obat dan makanan tidak ada, tidak makan obat pengencer darah, sudah puasa sejak 7 jam yang lalu. 
Pemeriksaan Fisis

G1P0A0, berat badan $72,5 \mathrm{~kg}$, tinggi badan 168 $\mathrm{cm}$, Mallampati skor 1, gigi goyang/gigi palsu tidak ada, lensa contact tidak ada. Tekanan darah 130/90 mmHg, laju nadi 97 x/menit, $\mathrm{SpO}_{2}$ 100\% dengan kanul binasal.

Pemeriksaan Penunjang

Hasil pemeriksaan penunjang terlihat pada tabel 1 dibawah ini.

Tabel 1. Pemeriksaan Prabedah

\begin{tabular}{|c|c|c|c|}
\hline Parameter & Hasil & Satuan & $\begin{array}{l}\text { Nilai } \\
\text { normal }\end{array}$ \\
\hline Ureum darah & 40 & $\mathrm{mg} / \mathrm{dl}$ & $15-40$ \\
\hline Kreatinin darah & 1,7 & $\mathrm{Mg} / \mathrm{dl}$ & $0,6-1,1$ \\
\hline $\begin{array}{l}\text { Gula darah } \\
\text { sewaktu }\end{array}$ & 103 & $\mathrm{Mg} / \mathrm{dL}$ & $<200$ \\
\hline $\begin{array}{l}\text { Autoimun CRP } \\
\text { FIA }\end{array}$ & 12,1 & $\mathrm{Mg} / \mathrm{L}$ & $<10$ \\
\hline $\mathrm{Hb}$ & 10,5 & $\mathrm{~g} / \mathrm{dL}$ & $\begin{array}{l}11,7- \\
15,5\end{array}$ \\
\hline Hematokrit & 30 & $\%$ & $35-47$ \\
\hline Leukosit & 8730 & $/ \mathrm{uL}$ & $\begin{array}{l}4500- \\
11300\end{array}$ \\
\hline Thrombosit & 339 & $\begin{array}{l}\text { Ribu/ } \\
\mathrm{uL}\end{array}$ & $150-450$ \\
\hline Eritrosit & 3,3 & Juta/uL & $3,8-5,2$ \\
\hline $\begin{array}{l}\text { Waktu } \\
\text { Pembekuan (CT) }\end{array}$ & 4,0 & menit & $2-6$ \\
\hline $\begin{array}{l}\text { Waktu } \\
\text { Perdarahan (BT) }\end{array}$ & & menit & $1-3$ \\
\hline SGOT & 46 & $\mathrm{U} / \mathrm{L}$ & $<31$ \\
\hline SGPT & 48 & $\mathrm{U} / \mathrm{L}$ & $<33$ \\
\hline \multicolumn{4}{|l|}{$\begin{array}{l}\text { Anti SARS- } \\
\text { COV-2 }\end{array}$} \\
\hline $\begin{array}{l}\text { Anti SARS- } \\
\text { CoV-2 IgM }\end{array}$ & $\begin{array}{l}\text { Non } \\
\text { Reaktif }\end{array}$ & & $\begin{array}{l}\text { Non } \\
\text { Reaktif }\end{array}$ \\
\hline $\begin{array}{l}\text { Anti SARS- } \\
\text { CoV-2 IgG }\end{array}$ & $\begin{array}{l}\text { Non } \\
\text { Reaktif }\end{array}$ & & $\begin{array}{l}\text { Non } \\
\text { Reaktif }\end{array}$ \\
\hline EKG & $\begin{array}{l}\mathrm{D} \text { a } 1 \text { a } \mathrm{m} \\
\mathrm{b} \text { a } \mathrm{t} \text { a } \mathrm{s} \\
\text { normal }\end{array}$ & & \\
\hline
\end{tabular}

\section{Pengelolaan Anestesi}

Diatas meja operasi pasien diposisikan miring ke kiri, diberikan oksigen melalui kanul binasal, tetap memakai masker bedah sesuai dengan protokol covid-19 di rumahsakit tersebut. Setelah diukur data dasar tekanan darah, saturasi oksigen, $\mathrm{EKG}$, pasien diinduksi dengan propofol 140 $\mathrm{mg}$, atracurium $35 \mathrm{mg}$, sambil diberi oksigen dengan sungkup muka yang ditempatkan diatas surgical mask pasien, kemudian dilakukan intubasi dengan endotracheal tube (ETT) no 6,5. Ventilasi mekanik dengan volume tidal $560 \mathrm{~mL}$, laju nafas $12 \times$ per menit, positive end expiratory pressure (PEEP) 5. Rumatan anestesi dengan $\mathrm{N}_{2} \mathrm{O} 50 \%$, sevofluran $1-2 \mathrm{vol} \%$. Analgetik fentanyl 100 ug diberikan setelah bayi lahir. Pasien diberikan cairan RL $500 \mathrm{~mL}$, gelofusin $500 \mathrm{~mL}$. Obat-obat lain: misoprostol $800 \mathrm{mcg}$ perrectal setelah dilakukan induksi anestesi, oxytocin $40 \mathrm{IU}$, methylergometrine $0,6 \mathrm{mg}$, asam traneksamat 1 gram, dextrose $40 \% 25 \mathrm{~mL}$. Pemantauan selama pembedahan terlihat pada grafik 1, dan menunjukkan keadaan yang stabil baik, kecuali nilai linear analog scale (LAS) antara 4 sampai 6 (grafik no 1 dan

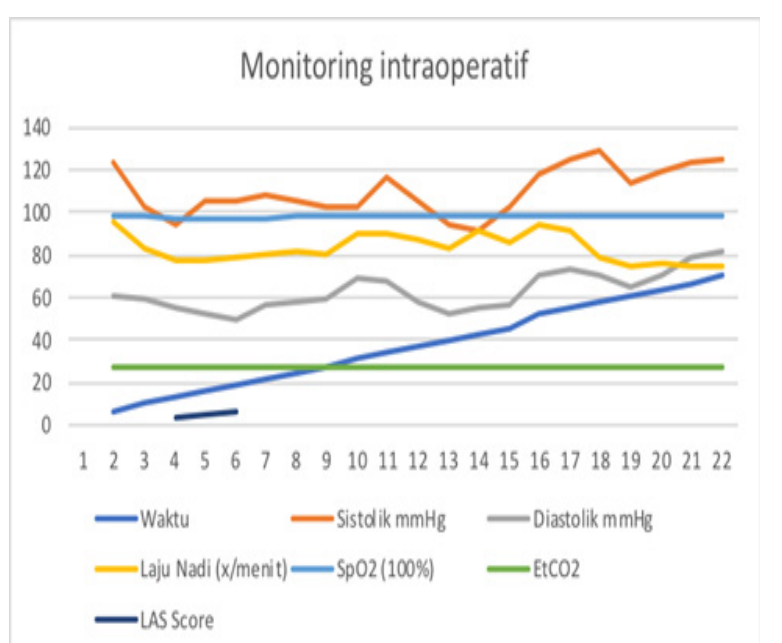

Grafik 1. Tekanan Darah (mmHg), laju nadi (x/menit), $\mathrm{SpO}_{2} \quad(\%), \quad \mathrm{EtCO}_{2} \quad(\mathrm{mmHg})$, LAS score

tabel no 2). Karena skor LAS tetap 4-6 setelah pemberian uterotonika lengkap, maka dilakukan pengikatan uterus dengan teknik B-Lynch. Induksi anestesi dilakukan jam 19.02, dilakukan pemasangan kateter urine dan dilakukan insisi kulit jam 19.16. Insisi uterus dilakukan jam 19.20 Bayi ke-1 lahir jam 19.21, BB 2650 gr, skor Apgar 1 menit dan 5 menit 9, 10. Bayi ke-2 lahir jam 19.22, BB 2100 gr, skor Apgar 1 menit dan 5 menit 
Tabel 2. Skor LAS setelah Bayi Lahir dan Penjahitan dengan Teknik B-Lynch

\begin{tabular}{ccccccc}
\hline $\begin{array}{c}\text { Waktu } \\
\text { setelah induksi) }\end{array}$ & $\begin{array}{r}\text { Tekanan Darah Laju } \\
(\mathrm{mmHg})\end{array}$ & $\begin{array}{r}\text { Nadi } \\
\text { menit })\end{array}$ & $(\mathrm{x} /$ & $\mathrm{SpO}_{2}(\%)$ & $\begin{array}{c}\mathrm{E} \mathrm{t} \mathrm{C} \mathrm{O} \\
(\mathrm{mmHg})\end{array}$ & Skor LAS \\
\hline 13 & $94 / 55$ & 78 & 98 & 28 & 4 \\
16 & $106 / 53$ & 78 & 98 & 28 & 5,6 \\
19 & $105 / 50$ & 79 & 98 & 28 & 6 \\
22 & $108 / 57$ & 80 & 98 & 28 & Uterus dijahit \\
\hline
\end{tabular}

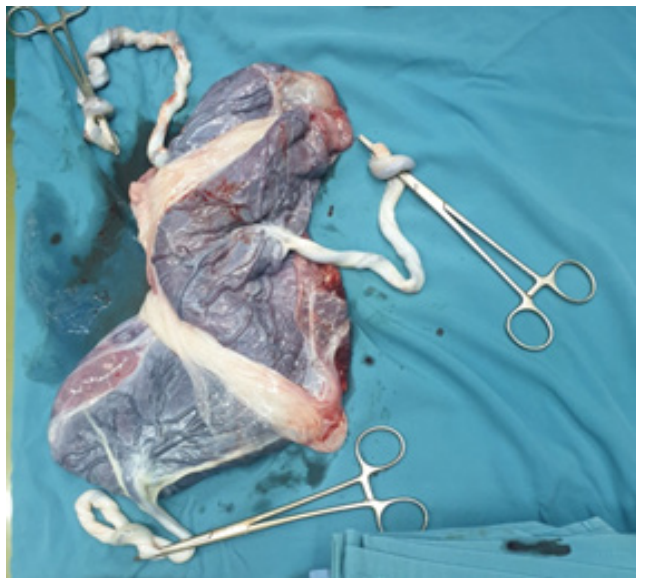

Gambar 2. Plasenta dengan 3 Tali Pusat

9, 10. Bayi ke-3 lahir jam 19.23, BB 1900 gr, skor Apgar 1 menit dan 5 menit 9, 10. Saat menutup peritoneum, diberi bolus analgetik dexketoprofen $50 \mathrm{mg}$ intravena. Selesai operasi jam 20.25, pasien akan dibangunkan, gas anestesi ditutup, direverse dengan prostigmin $1 \mathrm{mg}$ dan sulfas atropin 0,5 mg. Diuresis $500 \mathrm{~mL}$, jumlah perdarahan $600 \mathrm{~mL}$

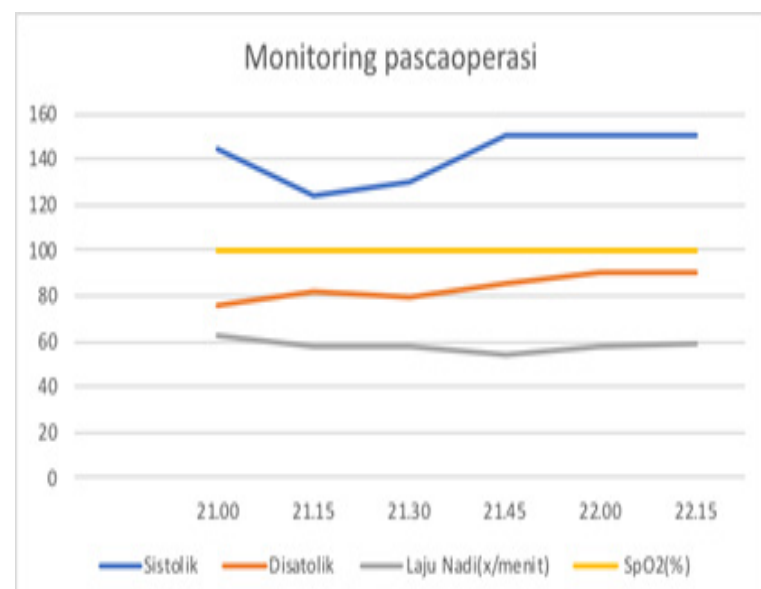

Grafik 2. Tekanan darah (mmHg), Laju nadi (x/ menit), $\mathrm{SpO}_{2}$ Pascabedah (\%)

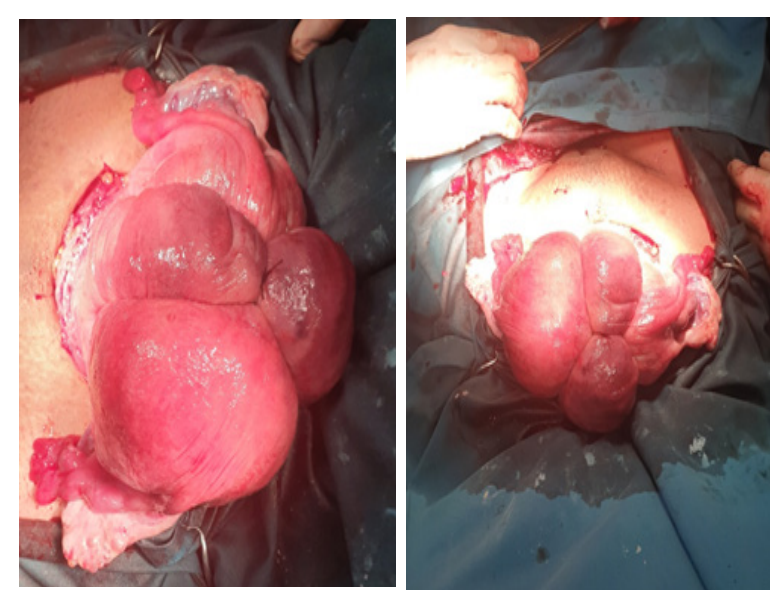

Gambar 3: Pengikatan Uterus, karena Skor LAS Tetap 6 setelah Pemberian Obat-obatan

\section{Pengelolaan Pascabedah}

Pascabedah pasien dirawat di ruang perawatan khusus (high care) untuk pemantauan hemodinamik, perdarahan pervaginam dan kontraksi uterus. Analgetik pascabedah dengan petidin $100 \mathrm{mg}$ dan dexketoprofen $100 \mathrm{mg}$ dilarutkan dalam $\mathrm{NaCl} 0,9 \% 50 \mathrm{~mL}$ diberikan untuk 24 jam dan fentanyl patch 12 ug. Walaupun terdapat kontraksi uterus dengan skor LAS 4-6, akan tetapi karena cepat dilakukan pemberian uterotonika dan penjahitan B-Lynch, pasien tidak kehilangan darah yang banyak dan hasil pemeriksaan $\mathrm{Hb}$ pascabedah adalah 10,0 g/dL,

Tabel 4. Hasil Lab Pascabedah

\begin{tabular}{llll}
\hline Parameter & Hasil & Satuan & Nilai Normal \\
\hline $\mathrm{Hb}$ & 10,0 & $\mathrm{~g} / \mathrm{dL}$ & $11,7-15,5$ \\
$\mathrm{Ht}$ & 29 & $\%$ & $35-47$ \\
Leukosit & 21.330 & $/ \mathrm{uL}$ & $4500-11300$ \\
Thrombosit & 284 & $\mathrm{Ribu} / \mathrm{uL}$ & $150-450$ \\
Eritrosit & 3,2 & $\mathrm{Juta} / \mathrm{uL}$ & $3,8-5,2$ \\
\hline
\end{tabular}


sehingga tidak memerlukan transfusi darah.

\section{Pembahasan}

\section{Komplikasi maternal}

Masalah bila anestesi untuk seksio sesarea dilakukan dengan spinal/epidural adalah adanya hipotensi maternal dan hipoperfusi plasental. Anestesi umum mempunyai masalah kemungkinan aspirasi dan gagal intubasi. Masalah pada anestesi umum sudah diperkirakan tidak ada karena operasi ini merupakan operasi elektif dan pasien sudah dipuasakan 8 jam sebelum operasi dari makanan padat, hanya diperbolehkan clear fluid sampai 2 jam preop. Masalah airway, pasien ini dengan Malampati 1, sehingga kemungkinan besar tidak ada kesulitan intubasi. Masalah yang masih perlu diperhatikan adalah kemungkinan gangguan kontraksi uterus pasca melahirkan. Pasien ini dipantau skor LAS nya dan karena hanya bisa mencapai skor LAS 6 setelah pemberian oxytocin, methylergometrin dan misoprostol (first line dan second line drugs), serta karena berdasarkan salah satu penelitian pemberian dextrose bisa memperbaiki kontraksi tetap 6 setelah pemberian obat-obatan, maka dilakukan pengikatan uterus dengan teknik B-Lynch suture. ${ }^{12}$ Teknik penjahitan seperti terlihat pada gambar dibawah ini.

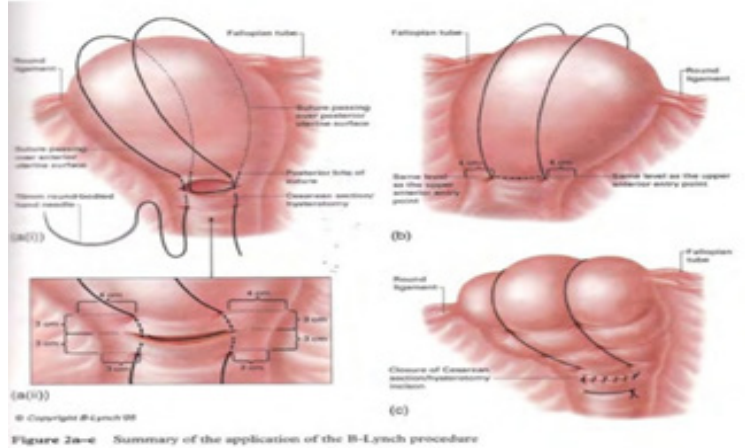

Gambar 1. Teknik B-Lynch Suture. ${ }^{13}$

Frekuensi preeklampsia lebih tinggi pada kehamilan triplet daripada kehamilan tunggal (10 lawan 3-5\%). Preeklampsi terjadi lebih segera dan lebih berat pada kehamilan multipel, dan kejadian hemolysis, elevated liver enzym, low platelet (HELLP) syndrome lebih sering. American College of Obstetrician and Gynecologist $(A C O G)$ dan the Society for maternal-fetal

Tabel 1. Morbiditas Maternal pada Kehamilan Multipel Versus Kehamilan Tunggal

\begin{tabular}{llll}
\hline Komplikasi Maternal & Kehamilan Tunggal (\%) & Kehamilan Multipel (\%) & Odd Rasio \\
\hline $\begin{array}{l}\text { Preeklampsi dan Hipertensi } \\
\text { dalam Kehamilan }\end{array}$ & 6 & 13 & 2,2 \\
Abruptio plasenta & 0,8 & 2 & 2,5 \\
Infeksi traktus urinarius & 6,7 & 8,7 & 2 \\
Anemia & 4 & 9 & 2 \\
Diabetes pada Kehamilan & 3 & $22-39$ & $7-13$ \\
Post-term gestasi & 4 & $<1$ & 0,2 \\
\hline
\end{tabular}

Dikutip dari: Zeev. ${ }^{14}$

uterus, maka diberikan $25 \mathrm{~mL}$ dextrose $40 \%$. Salah satu penelitian yang membandingkan pemberian dextrose $10 \%$ dengan oxytocin menunjukkan bahwa pemberian dextrose $10 \%$ pada kala 3 persalinan menunjukkan lebih rendahnya PPH dibandingkan dengan oxytocin. ${ }^{12}$ Managemen medikal PPH dengan menggunakan sintometrin, carboprost dan misoprostol. Akan tetapi, kadang-kadang menagemen medikal gagal dan diperlukan terapi pembedahan. Karena LAS medicine mendukung rekomendasi US Preventive Task Force tentang penggunaan dosis rendah aspirin $(81 \mathrm{mg} /$ hari) untuk mengurangi kejadian preeklampsi dan dihubungkan dengan komplikasi dari kelahiran prematur dan intrauterine growth restriction pada kehamilan multipel. Dosis rendah aspirin $81 \mathrm{mg} /$ hari dimulai antara 12 dan 28 minggu (optimalnya sebelum 16 minggu) dan diteruskan kontinyu sampai saat melahirkan. ${ }^{1}$ Pada pasien ini kehamilan triplet tanpa penyulit 
preeklampsi. Komplikasi kehamilan juga lebih sering terjadi pada kehamilan triplet daripada kehamilan tunggal. Diagnosis dan penanganannya sama seperti pada kehamilan tunggal. Komplikasi yang sering terjadi adalah mual-muntah, abruptio plasenta dilaporkan pada $1,6 \%$ kehamilan triplet dibandingkan dengan $<1 \%$ pada kehamilan tunggal, trombositopenia terjadi pada 1/3 kehamilan triplet yang penyebab utamanya adalah preeklampsi, acute fatty liver of pregnancy terjadi pada 7\% kehamilan triplet dibandingkan dengan 1/10.000 pada kehamilan tunggal, intrahepatic cholestasis lebih sering pada kehamilan multipel. ${ }^{1,15}$ Kehamilan multipel merupakan faktor risiko terjadinya atonia uteri yang menyebabkan terjadinya PPH. Depresi postpartum dan gangguan psikologis lainnya lebih sering terjadi pada kehamilan multipel. Juga dihubungkan dengan kejadian plasenta praevia, karena besarnya volume plasenta. Kehamilan multipel meningkatkan risiko terjadinya atonia uteri, PPH dan histerektomi emergensi. ${ }^{1,10,15-17}$

Dalam situasi pandemic covid, skrining yang dilakukan hanya rapid test antibody. Walaupun pasien ini rapid test covid non reaktif, tapi test ini tidak menghilangkan kemungkinan pasien terinfeksi covid-19, maka personil kamar operasi tetap menggunakan alat pelindung diri (APD) level 3 yang merupakan standar prosedur (SOP) di rumah sakit tersebut.

\section{Komplikasi Fetal dan Neonatal}

Pretrem labor dan preterm prematurity merupakan komplikasi yang paling sering terjadi. Morbiditas dan mortalitas neonatal secara nyata meningkat pada quadru dan quintuplets. Pada kasus ini berat badan bayi pertama 2650 gram, bayi kedua 2100 gram, dan bayi ketiga 1900 gram. Walaupun bayi kedua dan ketiga menunjukkan berat badan kurang dari 2500 gram, tapi semuanya menunjukkkan skor Apgar 1 menit 9 dan skor Apgar 5 menit 10. Berbagai komplikasi yang dapat timbul dapat dilihat pada tabel 2 dibawah ini.

Mode Melahirkan Bayi

Direkomendasikan anestesi neuroaksial karena

Tabel 2. Komplikasi Fetal pada Kehamilan Multipel versus Kehamilan Tunggal

\begin{tabular}{|c|c|c|c|c|c|}
\hline Komplikasi Fetal & Hamil Tunggal & Twins & Triplets & Quadruplets & $\begin{array}{l}\text { Quintuplets dan } \\
\text { Lebih }\end{array}$ \\
\hline Prematuritas & $4-6 \%$ & $50 \%$ & $90 \%$ & $>90 \%$ & $100 \%$ \\
\hline $\begin{array}{l}\text { Rata-rata lama kehamilan (min- } \\
\text { ggu) }\end{array}$ & 40 & $35-36$ & $32-33$ & 29,5 & $<29$ \\
\hline $\begin{array}{l}\text { Laju handicap/1000 yang hidup } \\
\text { postnatal }\end{array}$ & 90,6 & 125,6 & 178,1 & & \\
\hline $\begin{array}{l}\text { Handicap berat/100 yang hidup } \\
\text { postnatal }\end{array}$ & 19,8 & 33,7 & 57,1 & & \\
\hline $\begin{array}{l}\text { Cerebral palsy/1000 kelahiran } \\
\text { hidup }\end{array}$ & 1 & 4,6 & 16,6 & & \\
\hline Cerebral palsy/1000 kehamilan & 1 & 8,3 & 47 & & \\
\hline $\begin{array}{l}\text { Laju mortalitas tahun perta- } \\
\text { ma/1000 lahir hidup }\end{array}$ & 11 & 66 & 190 & & \\
\hline $\begin{array}{l}\text { Laju mortalitas neonatal/1000 } \\
\text { lahir hidup }\end{array}$ & $5-8$ & 56 & 169 & & \\
\hline BB rata-rata saat lahir (gram) & 3357 & 2350 & 1700 & $<1400$ & $<1300$ \\
\hline BB rata-rata $<1500$ gram & $1 \%$ & $11 \%$ & $32 \%$ & Hampir 100\% & $100 \%$ \\
\hline BB rata-rata $<2500$ gram & $6,06 \%$ & $52,24 \%$ & $91,52 \%$ & Hampir $100 \%$ & $100 \%$ \\
\hline Small for gestational age & $9-10 \%$ & $15-35 \%$ & $50 \%$ & $75-100 \%$ & $100 \%$ \\
\hline $\begin{array}{l}\text { Lama rata-rata tinggal di NICU } \\
\text { (hari) }\end{array}$ & - & 18 & 30 & 58 & $>60$ \\
\hline
\end{tabular}

Dikutip dari Zeev. ${ }^{14}$ 
dapat untuk melahirkan per vagina, seksio sesarea, versi internal dan eksternal, dan total breech extraction. ${ }^{1,14}$ Akan tetapi, seksio sesarea adalah rute yang disukai untuk melahirkan pasien dengan kehamilan triplet. Melahirkan pervaginal pasien triplet dihubungkan dengan meningkatnya risiko kelahiran mati, dan kematian neonatal dan infant dibandingkan dengan dilahirkan dengan seksio sesarea. ${ }^{6}$ Penelitian cohort multisenter di Amerika menunjukkan bahwa laju keberhasilan melahirkan per vagina hanya $16,7 \%$, dan melahirkan pervagina dihubungkan dengan lebih tinginya risiko transfusi ibu dan neonatal ventilasi mekanik, berarti meningkatkan morbiditas neonatal.,14

\section{Simpulan}

Pengelolaan anestesi untuk seksio sesarea kehamilan triplet memerlukan perencanaan yang baik untuk keselamatan ibu dan bayi. Masalah ibu adalah kemungkinan terjadi hipotensi, dan perdarahan postpartum, sedangkan permasalahan pada bayi adalah berat badan rendah. Persiapan yang baik secara multidisiplin antara dokter anestesi, dokter obgin dan dokter anak akan memperbaiki outcome ibu dan neonatal.

\section{Daftar Pustaka}

1. Hayes JE. Triplet pregnancy. UpToDate 2020 www.uptodate.com

2. Lachowska M, Paluszynska D, Fuchs T, Waytoh R, Zimmer M, KrolakOlejnik B. Neonatal outcome from triplet interval delayed delivery: a case report. Case Report in Obstetrics and Gynecology 2013; article ID 451360

3. Peress D, Dude A, Peaceman A, Yee LM. Maternal and neonatal outcome in triplet gestations by trial of labor versus planed cesarean delivery. J Matern Fetal Neonatal Med 2019;32(11):1874-79

4. Marino T, Goudas LC, Steinbok V, Craigo $\mathrm{SD}$, Yarnell RW. The anesthetic management of triplet cesarean delivery: a retrospective case series of maternal outcome. Anesth Analg $2001 \quad$ Oct;93(4):991-5

5. Hager M, Ott J, Castillo DM, Springer S, Seeman R, Pils S. Prevalence of gestational diabetes in triplet pregnancies: a retrospective cohort study and meta-analysis. J Clin Med 2020 May 18; 19(5):1523

6. Vintzileos AM, Ananth CV, Kontopoulos E, Smulian JC. Mode of delivery and risk of stillbirth and infant mortality in triplet gestations: United Sates 1995 through 1998. Am J Obstet Gynecol 2005;192:464

7. Su CW. Postpartum Hemorrhage. Prim Care Clin Office Pract 2012; 39:167-87

8. Ahonen J, Stefanovic V, Lassila R. management of post-partum haemorrhage. Acta Anaesthesiol Scand 2010;54:1164-78.

9. Jennings A, Brunning J, Brennan C. Management of obstetric haemorrhage. Anaesthesia tutorial of the week 257, WFSA, April 2012.

10. Evensen A, Anderson J. Postpartum hemorrhage: third stage pregnancy. ALSO January 2013Wali A, Suresh MS, Gregg AR. Antepartum hemorrhage. Dalam: Datta S. Anesthetic and Obstetric Management of High-risk Pregnancy. 3rd ed. New York: Springer; 2004, 87-109

11. Kim TS, Bae JS, Park JM, Kang SK. Hemodynamic effect of continuous intravenous injection and bolus plus continuous intravenous injection of oxytocin in caesarean section. Korean J Anesthesiol 2011;61:482-7

12. Suhrabi Z, Akbari M, Taghinejad H, Azami G. Comparing the effect of dextrose and oxytocin to reduce postpartum hemorrhage: randomized controlled trial. Journal of Clinical and Diagnostic Researxh 2019 Jul. 13(\&):QC09-QC11 
13. Balogun-Lynch C, Javaid TA. B-Lynch compression suture as an alternative to paripartum hysterectomi. http://dx.doi. org/10.5772/61295.

14. Zeev B, Abdallah W, Onit SG, Rachel BO. Triple gestation-Prevention, risks, \& management dilemmas. The Open Women's Health Journal 2008;2:11-21.

15. Francois K, Ortiz J, Harris C, Folley MR, Elliot JP. Is peripartum hysterectomy more common in multiple gestations? Obstet Gynecol 2005;105:1369-72.
16. Edhi MM, Aslam HM, Naqvi Z, Hashmi H. Postpartum hemorrhage: causes and management. BMC Research Notes 2013;6:236.

17. Borovac-Pinheiro A, Pacagnela RC, Cecatti JG, Duricher J, Blumenthal PD, Winikoff B. Postpartum hemorrhage: new insight for definition and diagnosis. AJOG 2018;219(2):162-68. 